\title{
Yield Loss of Cotton Cultivars Due to Rotylenchulus reniformis and the Added Benefit of a Nematicide
}

\author{
David R. Dyer, William Groover, and Kathy S. Lawrence ${ }^{\dagger}$ \\ Department of Entomology and Plant Pathology, Auburn University, Auburn, AL 36849
}

Accepted for publication 25 March 2020.

\begin{abstract}
The objective was to determine cotton yield loss due to Rotylenchulus reniformis and document any yield benefit from the addition of a nematicide. Field trials were established in two adjacent fields: one infested with $R$. reniformis and one where $R$. reniformis was not detected. In both fields, seven cotton cultivars were planted with and without Velum Total (1.02 liters/ ha). In 2017, R. reniformis reduced cultivar yields by an average of $59 \%$ between the noninfested and the $R$. reniformis-infested field. The nematicide application increased seed cotton yields

seed cotton yields by an average of $42 \%$ between the noninfested field and the $R$. reniformis-infested field. Across the cultivars, addition of the nematicide increased seed cotton yields by an average of $6 \%$ in the $R$. reniformis-infested field and an average of $8 \%$ in the noninfested field. The nematicide reduced $R$. reniformis eggs per gram of root by an average of 92\% in 2017 and $78 \%$ in 2018 across all cotton cultivars. Overall, $R$. reniformis reduced seed cotton yields by $50 \%$, which was equivalent to $2,225 \mathrm{~kg} / \mathrm{ha}$.
\end{abstract} in the $R$. reniformis field by $55 \%$, and no yield increase was observed in the noninfested field. In 2018, R. reniformis reduced
Keywords: cotton, reniform nematode, Velum Total, yield loss
First described by Linford and Oliveira (1940) in Hawaii, the reniform nematode, Rotylenchulus reniformis Linford \& Oliveira, is found in tropical, subtropical, and warm temperate regions around the world (Robinson et al. 1997). In the United States, the nematode quickly became one of the most commonly found plant pathogenic nematodes on cotton in the midsouth and southeast cotton regions. According to Robinson (2007), the reniform nematode has surpassed the root-knot nematode, Meloidogyne incognita (Kofoid and White) Chitwood, as the major nematode affecting cotton in Mississippi, Alabama, and Louisiana. In 2018, it was estimated that more than $1.2 \%$ of the cotton crop, equivalent to 204,700 bales, was lost due to $R$. reniformis across the United States Cotton Belt (Lawrence et al. 2019). In Alabama, the impact was more severe, with an estimated $3 \%$ yield loss or approximately 26,000 bales of cotton (Lawrence et al. 2019).

The $R$. reniformis nematode is described as a semiendoparasitic sedentary nematode with a host range of more than 314 plant species, including the regionally important agronomic crops of cotton and soybean (Wang 2013). In most situations, R. reniformis can be found in soil types with a high content of silt or clay (Moore and Lawrence 2013). In cotton fields, $R$. reniformis can spread via

${ }^{\dagger}$ Corresponding author: K. S. Lawrence; lawrekk@auburn.edu

Funding: The authors thank the Alabama Cotton Commission (project no. 16-241$\mathrm{AL}$ ) and the Hatch Project (project no. ALA015-2-14003) for their funding support that allowed them to conduct this research.

The author(s) declare no conflict of interest.

This article is in the public domain and not copyrightable. It may be freely reprinted with customary crediting of the source. The American Phytopathological Society, 2020 contaminated equipment and by the movement of water (Moore et al. 2010). Areas infested with $R$. reniformis typically have a high population density of the nematode due to a high potential rate of population increase compared with other nematodes because of its short life cycle, which can be as little as 17 days under optimal conditions (Robinson 2007). Economic threshold data for $R$. reniformis in cotton are scarce; however, Luc et al. (2005) suggests that the tolerance value is around 100 nematodes $/ 100 \mathrm{~g}$ of soil.

Symptoms of $R$. reniformis damage in cotton include reduced yield and stunting of the plant that can be described as a wave-type pattern of the canopy due to varying nematode population density throughout the field. However, given time, population density of the nematode will become more evenly distributed throughout the field and this wave-type pattern will become less apparent (Lawrence and McLean 2001). In some soils, interveinal chlorosis, commonly referred to as tiger striping, has been observed in the foliage as a result of the nematode pathogen (Land et al. 2015). Nematode infection also results in a reduced root mass with fewer feeder roots to supply the plant with water and nutrients, leading to poor growth (Lawrence and McLean 2001).

In general, nematode management consists of combining resistant cultivars, crop rotation, and application of nematicides. However, in cotton some of these management strategies are limited. Currently, no $R$. reniformis-resistant cotton cultivars are available to farmers, although breeding efforts to develop resistant cultivars are ongoing (Khanal et al. 2018). Crop rotation can be effective with crops such as corn, peanuts, sorghum, and other crops. However, these types of rotation crops are not always economically feasible for farmers. When crop rotations are effectively used, $R$. reniformis population densities have been shown to rebound in as little as 1 year when a field is planted back in cotton 
(Davis et al. 2003; Stetina et al. 2007). Currently, applications of nematicides in the form of seed treatments, in-furrow sprays, or granular applications are the most common form of nematode management in cotton. For this trial, the nematicide Velum Total (active ingredients fluopyram + imidacloprid [Bayer CropScience; Raleigh, NC]) was selected. Fluopyram is a nematistatic chemical documented to reduce $R$. reniformis infection at low concentrations (Faske and Hurd 2015). Imidacloprid is an insecticide commonly used as a cotton seed treatment to protect against early season insect pressure. This study was conducted to evaluate the performance of seven commonly grown cotton cultivars with and without the application of Velum Total in the presence and absence of $R$. reniformis.

\section{Establishment of Field Trials for Evaluation of Yield Loss Due to $R$. reniformis}

2017 trial. Seven commercially available cotton cultivars, which are planted on a large amount of cotton acreage of the Southeastern Cotton Belt and represent four commercial seed companies, were planted in the presence and absence of $R$. reniformis. The trial was planted in two adjacent fields: one that had a high population density of $R$. reniformis (latitude $34^{\circ} 41^{\prime} 10.27^{\prime \prime} \mathrm{N}$, longitude $86^{\circ} 53^{\prime} 1.17^{\prime \prime} \mathrm{W}$ ) and one in which the presence of the nematode was not detected (latitude $34^{\circ} 41^{\prime} 10.27^{\prime \prime} \mathrm{N}$, longitude $86^{\circ} 53^{\prime} 16.35^{\prime \prime} \mathrm{W}$ ). The nematode-infested field used in this study was infested with $R$. reniformis in 1997, and the population density increased in the first 10 years (Moore et al. 2008). At the initiation of this trial, two composite soil samples were collected: one from the $R$. reniformisinfested field and one from the adjacent noninfested field. From these samples, fields were determined to have initial $R$. reniformis soil population density of 5,005 and 0 vermiform life stages per $100 \mathrm{~cm}^{3}$ of soil, respectively. In each field, the seven cotton cultivars (Table 1) were planted with and without an application of Velum Total (fluopyram, $179.7 \mathrm{~g} / \mathrm{liter}$; imidacloprid, $260.0 \mathrm{~g} / \mathrm{liter}$ ), which was applied as an in-furrow spray at the time of planting. The applications were made using 8003 flat fan nozzles angled perpendicular to the row just in front of the planter closing wheels, at a rate of 1.02 liters/ha with a spray volume of 93.5 liters/ha.

The trial was planted at the Tennessee Valley Research and Extension Center near Belle Mina, AL, on May 9, 2017. In both fields, the trial was arranged in a randomized complete block design with five replications, and plots were set up as four rows 7.6-m long with $0.9-\mathrm{m}$ row spacing. A $1.9-\mathrm{m}$-wide alley separated each replication. The four-row plots had the left two rows untreated, and the right two rows received the in-furrow spray with Velum Total at planting, forming subplots (Fig. 1). The seven cotton cultivars were planted at a rate of 302,500 seeds/ha with a John Deere MaxEmerge

\section{TABLE 1}

Commercial cotton cultivars planted and their maturity in the 2017 and 2018 field trials conducted at the Tennessee Valley Research and Extension Center near Belle Mina, AL Relative maturity

Croplan 3885 B2XF

Deltapine $1522 \mathrm{~B} 2 \mathrm{XF}$

Deltapine 1646 B2XF

PhytoGen 333 WRF

PhytoGen 444 WRF

PhytoGen 487 WRF

Stoneville 6182 GLT planter (John Deere; Moline, IL) with Almaco cone planters (Almaco; Nevada, IA). Both the nematode-infested and the adjacent noninfested field have a Decatur silt loam (24\% sand, $49 \%$ silt, and $28 \%$ clay) soil type with $<1 \%$ organic matter and a $\mathrm{pH}$ of 6.5 . The trial was irrigated as needed using a lateral irrigation system. Harvest occurred on November 10, 2017, 185 days after planting (DAP), using a two-row cotton picker to harvest each subplot separately. Seed cotton yields obtained from each plot were weighed and recorded.

2018 trial. This trial was a repeat of the 2017 trial, which was planted in the same nematode-infested and noninfested fields. This trial was identical to the 2017 trial in experimental design, plot layout, planting methods, and harvest. The trials only differed in the planting and harvest dates, which were May 8 and October 5, 2018, respectively, $150 \mathrm{DAP}$. At the initiation of this trial, the $R$. reniformis-infested field and adjacent noninfested field had an initial soil population density of 4,620 and 0 vermiform life stages per $100 \mathrm{~cm}^{3}$ of soil, respectively.

Nematode sampling. Nematode samples were collected by using shovels to remove the roots of eight arbitrarily selected plants from each plot. In each plot, four plants were removed from the Velum Total-treated rows, and four were removed from the nontreated rows. Sampling was conducted on June 22, 2017 (44 DAP), and on June 13, 2018 (36 DAP). These sampling dates had similar cotton growth stage, and the amount of growing degree days that had accumulated since planting on May 9, 2017, and May 8, 2018, were similar (2017 trial: 682; 2018 trial: 646). $R$. reniformis eggs were extracted from the cotton roots by a modification of the method of Hussey and Barker (1973). The roots were placed in a $0.625 \% \mathrm{NaOCl}$ solution and shaken for $4 \mathrm{~min}$ at $120 \mathrm{rpm}$ and $1 \times g$ force on a Barnstead LabLine Max Q 5000E class shaker (Conquer Scientific; San Diego, CA). Nematode eggs were rinsed from the roots with tap water and collected on a $25-\mu \mathrm{m}$-pore sieve. Nematode eggs were then processed by sucrose centrifugation-flotation at $240 \times g$ for $1 \mathrm{~min}$ (Jenkins 1964). Samples of $R$. reniformis eggs were then enumerated under a Nikon TSX 100 inverted microscope (Nikon; Tokyo, Japan) at $40 \times$ magnification. Eggs per gram of root were calculated by taking the ratio of total eggs extracted per the root fresh weight by subplot and averaged across replications by treatment.

Statistical analysis. Data were analyzed by ANOVA using Proc Glimmix via SAS 9.4 (SAS Institute; Cary, NC), with 280 experimental units per parameter measured. Means were separated using Tukey HSD test at the $P \leq 0.05$ level. Student panels were produced to determine the normality of the residuals. In the case of nematode

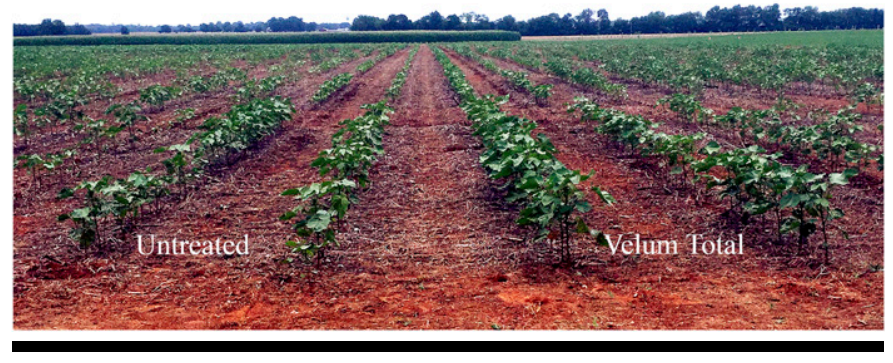

\section{FIGURE 1}

Trial plot containing Croplan 3885 B2XF cultivar 43 days after planting in 2018. The left two rows shown in the picture are the cultivar planted without the application of a nematicide. The right two rows were treated with an infurrow spray of Velum Total ( 1.02 liters/ha) at the time of planting. 
eggs per gram of root, the data were log-transformed to satisfy the ANOVA assumptions of normally distributed residuals. Correlations and regression were analyzed using Proc Corr and Proc Reg. A fourway interaction analysis was conducted with the year, presence of the nematode, application of the nematicide, and cotton cultivar as the four variables. Trial results differed greatly between 2017 and 2018 , so analysis was separated by year as a three-way interaction; source of variation in the data can be seen in Table 2 .

Cotton yields and nematode population density. In the 2017 trial, a significant reduction in cotton yield was observed in the presence of $R$. reniformis $(P<0.0001)$ as well as an associated increase in yield with the application of Velum Total $(P<0.0001)$ in the nematode-infested field. A significant interaction of the presence of the nematode and the application of Velum Total $(P<0.0001)$ was also observed (Table 2 ), because the seed cotton yield was increased by the application of Velum Total only in the field with $R$. reniformis present. $R$. reniformis significantly reduced seed cotton yield averaged over all cultivars in the infested field by $2,429 \mathrm{~kg} / \mathrm{ha}$ (59\%) compared with the noninfested field (Table 3 ). In the $R$. reniformis-infested field an initial soil population density of 5,005 vermiform life stages per $100 \mathrm{~cm}^{3}$ of soil was recorded. This resulted in an eggs per gram of root population of 5,023 in the untreated plots at 44 DAP; however, an in-furrow spray of Velum Total provided early season nematode protection and reduced root population density by $91 \%$ at 44 DAP (Table 3). This reduction in the nematode root population density increased early season plant growth measured in plant height and plant fresh weights by 20 and $70 \%$, respectively (data not shown), which can be seen in Figure 1. This increase in early season growth resulted in an increase in seed cotton yields in the field by $1,389 \mathrm{~kg} / \mathrm{ha}$. However, this yield increase due to the addition of the nematicide was not equivalent to the yield of the noninfested field (4,077 kg/ha averaged over all cotton cultivars). In the noninfested field, no yield effect was observed in response to the application of Velum Total. All cultivars produced statistically similar seed cotton yields in both fields. PhytoGen 444 WRF produced the greatest yields when grown in the noninfested field; however, this cultivar's yield potential was reduced $39 \%$ when grown in the presence of the nematode (Table 4). In the R. reniformisinfested field, the highest yielding cultivar was Deltapine 1522 $\mathrm{B} 2 \mathrm{XF}$, and this cultivar's yield potential was only reduced $16 \%$

TABLE 2

Source of variation for seed cotton yield (kg/ha) and Rotylenchulus reniformis eggs per gram of root in 2017 and 2018 conducted at the Tennessee Valley Research and Extension Center near Belle Mina, AL

\begin{tabular}{|c|c|c|c|c|}
\hline \multirow[b]{2}{*}{ Source of variation ( $F$ statistic) } & \multicolumn{2}{|r|}{2017} & \multicolumn{2}{|r|}{2018} \\
\hline & $\begin{array}{l}\text { Seed cotton yield } \\
185 \text { DAPw }\end{array}$ & $\begin{array}{c}\text { R. reniformis eggs/g of root } \\
44 \text { DAP }\end{array}$ & $\begin{array}{c}\text { Seed cotton yield } \\
150 \text { DAP }\end{array}$ & $\begin{array}{c}\text { R. reniformis eggs/g of root } \\
36 \text { DAP }\end{array}$ \\
\hline R. reniformis & $156.61 * * * * x$ & $\ldots$ & $730.32 * * * *$ & $\ldots$ \\
\hline Velum Total ${ }^{\mathrm{y}}$ & $24.09 * * * *$ & $88.02 * * * *$ & $12.64 * * *$ & $23.62 * * * *$ \\
\hline Cultivar $^{z}$ & 1.32 & 0.32 & 8.25 & $2.03^{*}$ \\
\hline R. reniformis $\times$ Velum Total & $27.55 * * * *$ & $\ldots$ & 2.09 & $\ldots$ \\
\hline $\begin{array}{l}R \text {. reniformis } \times \text { Velum Total } \times \\
\text { cultivar }\end{array}$ & 0.32 & $\cdots$ & 0.27 & $\cdots$ \\
\hline
\end{tabular}

${ }^{\mathrm{w}} \mathrm{DAP}=$ days after planting.

x Significance at the $P \leq 0.1,0.05,0.01$, and 0.001 level is indicated by $* * *, * * *$, and $* * * *$, respectively.

y Velum Total (fluopyram + imidacloprid) was applied at planting as an in-furrow spray at 1.02 liters/ha.

${ }^{z}$ Cultivars included in this study were Croplan 3885 B2XF, Deltapine 1522 B2XF, Deltapine 1646 B2XF, PhytoGen 333 WRF, PhytoGen 444 WRF, PhytoGen 487 WRF, and Stoneville 6182 GLT.

\begin{tabular}{|c|c|c|c|}
\hline \multicolumn{4}{|c|}{$\begin{array}{l}\text { TABLE } 3 \\
\text { Seed cotton yields and average population density of Rotylenchulus reniformis eggs per gram of root in the noninfested and } R \text {. } \\
\text { reniformis-infested fields for both the } 2017 \text { and } 2018 \text { growing seasons at the Tennessee Valley Research and Extension Center } \\
\text { near Belle Mina, AL }\end{array}$} \\
\hline Season, treatment & $\begin{array}{c}\text { Non-R. reniformis field } \\
\text { Yield (kg/ha) }\end{array}$ & Yield (kg/ha) & Eggs/g of root \\
\hline \multicolumn{4}{|l|}{2017} \\
\hline \multicolumn{4}{|l|}{2018} \\
\hline Untreated & $4,824 \pm 558$ & $2,804 \pm 669$ & $337 \pm 375 a$ \\
\hline Velum Total & $5,220 \pm 579$ & $2,971 \pm 584$ & $75 \pm 109 b$ \\
\hline
\end{tabular}

${ }^{\mathrm{x}} R$. reniformis nematode eggs per gram of root; they were present in the $R$. reniformis-infested field and not the noninfested field. Data present are least squares means, and significant values are based on log-transformed data to satisfy the assumptions of normality.

y Values present are least squares means separated using Tukey's HSD test at $P \leq 0.05$ as well as standard deviations, and values followed by different letters differ significantly. No letters present means that no significant difference was observed.

${ }^{\mathrm{z}}$ Velum Total (fluopyram + imidacloprid) was applied at planting as an in-furrow spray at 1.02 liters/ha. 
when grown in the presence of $R$. reniformis compared with the noninfested field (Table 4).

In the 2018 trial a significant effect on yield was observed from the presence of $R$. reniformis $(P<0.0001)$ and the application of Velum Total $(P<0.0001)$, and a significant interaction was observed between the presence of the nematode and the cultivar planted $(P<0.0001)$ (Table 2$)$. In 2018 , similarly to 2017 , yield reductions were measured in the $R$. reniformis-infested field compared with the noninfested fields. The presence of $R$. reniformis in the field at an initial soil population density of 4,620 vermiform life stages per $100 \mathrm{~cm}^{3}$ of soil resulted in a yield loss of $42 \%(2,020$ $\mathrm{kg} / \mathrm{ha}$ ) when compared with the noninfested field (Table 3). $R$. reniformis eggs per gram of root observed at 36 DAP were $78 \%$ lower with the application of Velum Total. However, the overall $R$. reniformis population density of the field was much lower when samples were collected compared with 2017. With this lower population density, we did not observe an increase in early season plant growth (data not shown) or final seed cotton yields that we observed in the previous year of testing. There was no significant $(P \leq 0.05)$ variation in nematode root population density among the seven cotton cultivars tested. In this trial, significant differences were observed $(P \leq 0.05)$ in seed cotton yield among the cotton cultivars (Table 5). In the noninfested field, Deltapine 1522 B2XF and Deltapine 1646 B2XF were the highest yielding cultivars. Deltapine $1522 \mathrm{~B} 2 \mathrm{XF}$ was also the highest performing cultivar in the $R$. reniformis field, producing significantly $(P \leq 0.05)$ increased seed cotton yield over PhytoGen 333 WRF and PhytoGen 444 WRF in both the control and Velum Total-treated plots.

\section{Impacts on Nematode Management and Cotton Production}

Through this research, we were able to quantify the actual yield loss attributed to $R$. reniformis in a cotton field as well as potential benefit from the application of a nematicide (Velum Total) with modern cotton cultivars. Overall, the seed cotton yield was negatively correlated with the $R$. reniformis root population density at 35 to 40 DAP. We observed a $25.83 \mathrm{~kg} / \mathrm{ha}( \pm 5.6 ; \pm 95 \%$ confidence interval) reduction in seed cotton yield for every 100 eggs/g of root increase in nematode root population density $(P<$ $\left.0.0001, R^{2}=0.23\right)$. In this model, the nematode root population density accounted for $23 \%$ of the variation in the seed cotton yield. The yield loss caused by $R$. reniformis averaged $50 \%$ between the two years when all cultivars and treatments were compared. Yield loss due to $R$. reniformis observed in this set of trials was higher than previous reports. We were able to determine actual yield losses utilizing the paired fields: one where $R$. reniformis was present and one where it was not. Previous reports estimated yield losses ranging from 38 to $45 \%$ (Jones et al. 1959; Robinson et al. 2005). By using the noninfested field, we were able to measure the yield potential of each cotton cultivar so that the yield loss attributed to the nematode could be more accurately estimated.

\begin{tabular}{|c|c|c|c|c|}
\hline \multicolumn{5}{|c|}{$\begin{array}{l}\text { TABLE } 4 \\
\begin{array}{l}\text { Seed cotton yield (kg/ha) harvested } 185 \text { days after planting by cotton cultivar in the noninfested and Rotylenchulus reniformis- } \\
\text { infested fields at the Tennessee Valley Research and Extension Center, 2017, near Belle Mina, AL }\end{array}\end{array}$} \\
\hline \multirow[b]{2}{*}{ Cotton cultivar } & \multicolumn{2}{|c|}{ Non-R. reniformis field } & \multicolumn{2}{|c|}{ R. reniformis-infested field } \\
\hline & No nematicide & Nematicidey & No nematicide & Nematicide \\
\hline Croplan 3885 B2XF & $3,709 \pm 742^{z}$ & $3,821 \pm 903$ & $2,060 \pm 901$ & $3,182 \pm 871$ \\
\hline Deltapine 1522 B2XF & $4,120 \pm 877$ & $4,249 \pm 1,128$ & $2,097 \pm 654$ & $3,547 \pm 1,121$ \\
\hline PhytoGen 444 WRF & $4,702 \pm 167$ & $4,762 \pm 650$ & $1,529 \pm 1,200$ & $2,883 \pm 911$ \\
\hline PhytoGen 487 WRF & $3,994 \pm 924$ & $4,064 \pm 1,321$ & $1,892 \pm 906$ & $3,258 \pm 986$ \\
\hline Stoneville 6182 GLT & $4,128 \pm 714$ & $4,047 \pm 721$ & $1,745 \pm 518$ & $3,061 \pm 395$ \\
\hline
\end{tabular}

y Velum Total (fluopyram + imidacloprid) was applied at planting as an in-furrow spray at 1.02 liters/ha.

${ }^{z}$ Values present are least squares means separated using Tukey's HSD test at $P \leq 0.05$ as well as standard deviations, and values in the same column followed by different letters differ significantly. Lack of letters present indicates no significant difference was observed.

\begin{tabular}{|c|c|c|c|c|}
\hline $\begin{array}{r}\text { Seed cotton yield ( } \\
\text { infes }\end{array}$ & $\begin{array}{l}\text { ed } 150 \text { days a } \\
\text { he Tennessee }\end{array}$ & $\begin{array}{l}\text { TABLE } 5 \\
\text { by cotton cul } \\
\text { arch and Exten }\end{array}$ & $\begin{array}{l}\text { ninfested an } \\
2018 \text {, near } B e\end{array}$ & Ius reniformis- \\
\hline & Non- & field & R. reni & d field \\
\hline Cotton cultivar & No nematicide & Nematicidey & No nematicide & Nematicide \\
\hline Croplan 3885 B2XF & $4,480 \pm 351 b c^{z}$ & $4,919 \pm 544 \mathrm{ab}$ & $2,859 \pm 359 a b$ & $3,049 \pm 438 a b$ \\
\hline Deltapine 1522 B2XF & $5,323 \pm 536 a$ & $5,457 \pm 680 a$ & $3,628 \pm 375 a$ & $3,701 \pm 615 a$ \\
\hline PhytoGen 444 WRF & $4,778 \pm 595 a b c$ & $5,388 \pm 522 a$ & $2,162 \pm 211 b$ & $2,733 \pm 291 b$ \\
\hline PhytoGen 487 WRF & $4,731 \pm 567 a b c$ & $5,107 \pm 583 a b$ & $3,036 \pm 601 \mathrm{ab}$ & $3,034 \pm 795 a b$ \\
\hline Stoneville 6182 GLT & $4,246 \pm 395 \mathrm{c}$ & $4,597 \pm 365 b$ & $2,865 \pm 425 \mathrm{ab}$ & $2,599 \pm 411 b$ \\
\hline
\end{tabular}

y Velum Total (fluopyram + imidacloprid) was applied at planting as an in-furrow spray at 1.02 liters/ha.

${ }^{\mathrm{z}}$ Values present are least squares means separated using Tukey's HSD test at $P \leq 0.05$ as well as standard deviations, and values in the same column followed by different letters differ significantly. 
Between the two trials, we observed variable results in the performance of Velum Total, which produced a 55\% yield increase over untreated plots in 2017 and only a $6 \%$ increase in 2018. This is could be due to the effects of soil moisture at the time of planting and early part of the cotton-growing season. Through the first 45 DAP, the 2017 trial received more than double the rain of the 2018 trial, $19.66 \mathrm{~cm}$ in 2017 and $8.71 \mathrm{~cm}$ in 2018 (Figs. 2 and 3 ). This low rainfall resulted in unusually dry conditions at the time of planting and the time of nematode sampling, and lack of moisture could have affected the nematicide efficacy. This issue of lack of yield response following a chemical application has been

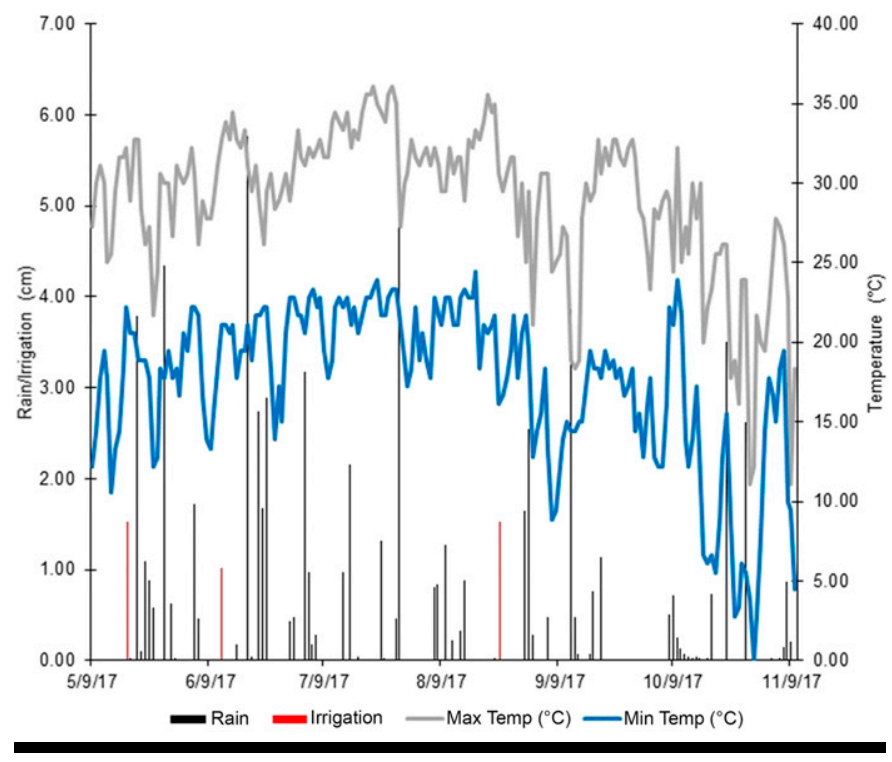

FIGURE 2

Rain, irrigation events, and temperatures from time of planting until harvest at the Tennessee Valley Research and Extension Center, 2017, near Belle Mina, AL.

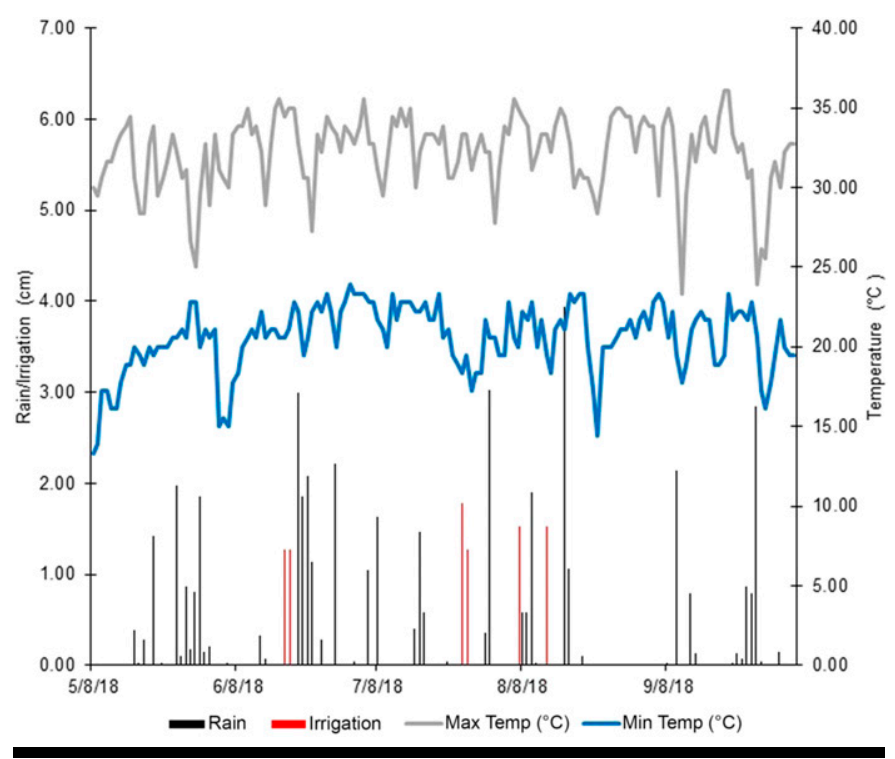

FIGURE 3

Rain, irrigation events, and temperatures from time of planting until harvest at the Tennessee Valley Research and Extension Center, 2018, near Belle Mina, AL. reported with other nematicides (Gazaway et al. 2001). Although no significant effect from the application of Velum Total was observed in seed cotton yield in 2018, a small numerical increase was observed in both the nematode-infested and noninfested field, 6 and $8 \%$ respectively.

The use of nematicides to manage $R$. reniformis in cotton is essential due to limitations in other control measures such as the lack of cotton cultivars with resistance. All cotton cultivars in this trial supported a similar nematode root population density, demonstrating that at least until the release of resistant cotton cultivars, $R$. reniformis management in cotton will continue to rely on the use of chemical nematicides. In this study, Velum Total was useful for lowering nematode root population density, and under good growing conditions, this resulted in an increased yield.

\section{Acknowledgments}

We thank Chet Norris, David Harkins, and Bradley Durham at the Tennessee Valley Research and Extension Center for their help in planting, maintaining, and harvesting these cotton trials.

\section{Literature Cited}

Davis, R. F., Koenning, S. R., Kemerait, R. C., Cummings, T. D., and Shurley, W. D. 2003. Rotylenchulus reniformis management in cotton with crop rotation. J. Nematol. 35:58-64.

Faske, T. R., and Hurd, K. 2015. Sensitivity of Meloidogyne incognita and Rotylenchulus reniformis to fluopyram. J. Nematol. 47:316-321.

Gazaway, W. S., Akribidge, J. R., and McLean, K. 2001. Impact of nematicides on cotton production in reniform infested fields. Page 1:128 in: Proceedings of the Beltwide Cotton Conference.

Hussey, R. S., and Barker, K. B. 1973. A comparison of methods of collecting inocula for Meloidogyne spp., including a new technique. Plant Dis. Rep. 57: 1025-1028.

Jenkins, W. R. 1964. A rapid centrifugal-flotation technique for separating nematodes from soil. Plant Dis. Rep. 48:692.

Jones, J. E., Newsom, L. D., and Finley, E. L. 1959. Effect of reniform nematode on yield, plant characters, and fiber properties of upland cotton. Agron. J. 51: 353-356.

Khanal, C., McGawley, E. C., Overstreet, C., and Stetina, R. 2018. The elusive search for reniform nematode resistance in cotton. Phytopathology 108: 532-541.

Land, C., Lawrence, K. S., Cobine, P., and Lawrence, G. 2015. Tiger striping symptoms caused by Rotylenchulus reniformis in upland cotton. Pages 1: 195-199 in: Proceedings of the Beltwide Cotton Conference.

Lawrence, G. W., and McLean, K. S. 2001. Reniform nematodes. Pages 42-43 in Compendium of Cotton Diseases. T. L. Kirkpatrick and C. S. Rothrock, eds. APS Press, St. Paul, MN.

Lawrence, K., Hagan, A., Norton, R., Hu, J., Faske, T., Hutmacher, R., Muller, J., Small, I., Grabau, Z., Kemerait, B., Overstreet, C., Price, P., Allen, T., Atwell, S., Idowu, J., Thiessen, L., Byrd, S., Goodson, J., Young, H., Wheeler, T., Isakeit, T., and Mehl, H. 2019. Cotton disease loss estimate committee report, 2018. Pages 1:54-56 in: Proceedings of the Beltwide Cotton Conference.

Linford, M. B., and Oliveira, J. M. 1940. Rotylenchulus reniformis, nov. gen., n. sp., a nematode parasite of roots. Proc. Helminthol. Soc. Wash. 7:35-42.

Luc, M., Sikora, R. A., and Bridge, J., eds. 2005. Plant Parasitic Nematodes in Subtropical and Tropical Agriculture, 2nd Ed. CABI Publishing, Wallingford, U.K.

Moore, S., and Lawrence, K. 2013. The effect of soil texture and irrigation on Rotylenchulus reniformis and cotton. J. Nematol. 45:99105.

Moore, S., Lawrence, K., Arriaga, F., Burmester, C., and van Santen, E. 2010. Natural mitigation of Rotylenchulus reniformis in a no-till cotton system. J. Nematol. 42:307-312.

Moore, S., Lawrence, K., Arriaga, F., Van Santan, E., and Burmester, C. 2008. Dimensional movement of Rotylenchulus reniformis thorough a Decatur silt loam soil under variable soil moistures. Pages 1:221-226 in: Proceedings of the Beltwide Cotton Conference.

Robinson, A. F. 2007. Reniform in U.S. cotton: When, where, why, and some remedies. Annu. Rev. Phytopathol. 45:263-288. 
Robinson, A. F., Cook, C. G., Westphal, A., and Bradford, J. M. 2005. Rotylenchulus reniformis below plow depth suppresses cotton yield and root growth. J. Nematol. 37:285-291.

Robinson, A. F., Inserra, R. N., Caswell-Chen, E. P., Coclas, N., and Troccoli, A. 1997. Rotylenchulus species: Identification, distribution, host ranges, and crop plant resistance. Nematropica 27:127-180.
Stetina, S. R., Young, L. D., Pettigrew, W. T., and Bruns, H. A. 2007. Effect of corn-cotton rotations on reniform nematode populations and crop yield. Nematropica 37:237-248.

Wang, K. 2013. Reniform nematode, Rotylenchulus reniformis Linford and Oliveria (Nematoda: Tylenchida: Tylenchoidea: Hoplopaimida: Rotylenchulinae). IFAS Extension EENY-210. University of Florida, Gainesville, FL. 